\title{
A Study of the Film Adaptations of Marek Hłasko's Prose by the Students of the Film School in Łódź
}

Images

vol. X/no.19

Poznań 2012

ISSN 1731-45OX

The works of Marek Hłasko have proved a reliable source of content and inspiration in Polish culture from the time of their writing to the current day, and this is typified by the number of film adaptations that have been made of his literature. This article considers first Hłasko's prose[1] in terms of its subject matter and themes, then overviews some particular examples of adaptations made by students of the celebrated Łódź Film School, and reflects on how these have remained faithful or deviated from Hłasko's original works, before concluding as to the reasons why the students may have been drawn to this particular source.

Hłasko's debut book titled The First Step In the Clouds (Pierwszy krok $w$ chmurach), was an extraordinary literary achievement that brought great fame to the author and provided the basis for several film adaptations. The writer was swiftly hailed the most outstanding literary talent that had appeared in post-war Poland. Newspapers contained many reviews of his short stories and his work was discussed and debated by the most important contemporary critics, writers and scholars of literature. Marek Hłasko was also considered something of a celebrity, in no small part due to his scandalous personal life, and by the age of twenty-two had become one of the most popular figures of the 1950s.

There are many characteristics that can be identified as being prevalent in Hłasko's works published in Poland.

In terms of location, most of Hłasko's prose is set in Warsaw, with the urban bustle of the city's streets, cafes and public houses providing the backdrop for dialogue and action, emphasising their dirtiness and crowdedness to enable the reader to share his characters' feelings of claustrophobia and fear as they are subjected to verbal, and sometimes physical, assault from unsavoury aggressors.[2]

[1] Hłasko's short stories that were written while the author lived in Poland are collected in the book The First Step in the Clouds (Pierwszy krok w chmurach), featuring a short story with the same name, and were written up to the year 1956, the same year the book was published. In 1958 Hłasko moved abroad. Although he continued to produce short stories while abroad, none of those works are considered here. [2] Some characters who are mocked and assaulted are Kuba in The Noose (Pętla), Pietrek and Agnieszka in The Eight Day of the Week (Ósmy dzień tygodnia) and the couple in love in The First Step in the Clouds (Pierwszy krokw chmurach). 
Hłasko's characters are mostly young men[3] and several types are distinguishable; immature boys searching for values[4], working men[5], men seeking love or friendship [6], and men who are loved by women[7] yet remain lonely, defeated and damaged. [8] They struggle with problems of a loveless existence, friendship, desire and, in response, often enter a state of rebellion or denial. Their attitudes demonstrate some major themes and tenets in Hłasko's literature, being a desire for rules, the search for ideals and values, and ultimately faith in the human condition through purity, love, friendship, honour, truth, and even work. Personal desires and ideals are seen to clash with brutal reality, and this often provides the strongest drama experienced by his characters. Disappointment and disillusionment are also prevalent themes in most of Hłasko's stories, the writer illustrating these to be present in almost every sphere of people's lives.

Marek Hłasko's world is frequently built on contrast. Most often these are the opposites of love and betrayal, beauty and ugliness, purity and filth, truth and lies, dreams (illusions, imagination) and reality (brutal, disappointing).

There are no philosophical solutions for the way of the world, or proffered explanations of the role and influence of historical events.[9] In their stead are important existential problems encountered in scenes depicting the experiences of individuals. Hłasko's style is simple and emotional, creating an atmosphere of normality and everyday life, centred and focussed on the individual almost in isolation, enabling their experiences with the external world to abruptly intrude on the narrative as they do on the characters themselves.

Marek Hłasko was himself fascinated with cinema and sought to use film for his artistic output. He wrote dialogues and screenplays, worked with many different filmmakers and, demonstrating rare prolificacy, within only two years (1956-58) Hłasko authored or co-

[3] An exception is The Eight Day of the Week (Ósmy dzien tygodnia) a story where the main character Agnieszka is a twenty-three year old student of philosophy.

[4] The Window (Okno).

[5] The Sokolowska Depot (Baza Sokołowska), A House (Dom), The Workers (Robotnicy), We Fly off into the Sky (Odlatujemy w niebo), Next Stop - Paradise (Nastęny do raju).

[6] Two Men on the Road (Dwaj mężczyźni na drodze), We Fly off into the Sky (Odlatujemy w niebo), The First Step in the Clouds (Pierwszy krok w chmurach), The Most Sacred Words of Our Life (Najświętsze słowa naszego życia), Pawnshop of Illusions (Lombard złudzeń), The Eight Day of the Week (Ósmy dzień tygodnia).
[7] A Soldier (Żolnierz), Pawnshop of Illusions (Lombard złudzeń), The Noose (Pętla).

[8] Slave's Market (Targ niewolników), My Mother's House (Dom mojej matki), The Window (Okno), The Letter (List), Finis Perfectus (Finis Perfectus), Two Men on the Road (Dwaj mężczyźni na drodze), The Soldier (Żolnierz), Drunk at Noon (Pijany o dwunastej w potudnie), The Noose (Pętla), Doctor X's Plankton (Planktony doktora X), Next Stop - Paradise (Następny do raju).

[9] It is seen the most in the dialogue of The Eighth Day of the Week (Ósmy dzień tygodnia) between Agnieszka and Grzegorz or Pietrek when they talk about the Party and history. 
authored the screenplay and dialogues of six films.[10] He also behaved as if he were an actor himself, moreover a film star, stoking further interest originally generated by his work and helping to bring himself to wider attention.

A significant and noteworthy aspect of Hłasko's work was to create stories written from the perspective of the eye of the camera. These stories appeared to be like ready-made scenarios thanks to their extensive and dominant dialogues, minimal descriptive content, quick and swift action, clearly delineated conflicts and coherent composition and, which is also important, behaviourism and lack of metaphysical depth.

Hłasko's writing style, as described above, was a revelation for Polish filmmakers. In contrast to the optimistic and artificial picture painted by communist propaganda, here were powerful and accurate portraits of the miserable reality faced by many of the time in text form that needed very little amendment to be ready for the screen. This is an especially important point as there were no professional screenwriters, nor screenwriting tradition, in Poland in the 1950s. This was not the only reason students of Łódź adapted Hłasko's work as after 1958 many followed his style in producing literature, scenarios and film dialogues[11], yet up to the present day many students have still concentrated on Hłasko.

Three films have been made by students from Łódź based on Hłasko's story entitled The First Step In the Clouds (Pierwszy krok $w$ chmurach), about a young couple in love looking to physically express their feelings for the first time, but are interrupted by the malevolent interference of three elder blue-collar workers who, unprovoked and bored by their own monotonous lives, pummel the boy and verbally attack the girl.

The Suburb (Przedmieście), directed by Lidia Zonn[12] in 1957, is the first film adaptation of this popular Hłasko story. This film takes on a didactic structure with the narrator providing a commentary on the thoughts and motivations behind the actions of the workers whom we can watch, but cannot hear, on the screen. The narrator reads

[10] Three of them are adaptations of his stories: The Noose (Pętla) made by Wojciech Jerzy Has in 1957, The Eighth Day of the Week (Ósmy dzien tygodnia) by Aleksander Ford (1958) and The Depot of the Dead (Baza ludzi umarlych) by Czesław Petelski in 1958. For the others Hłasko co-wrote screenplays or dialogues: The End of the Night (Koniec nocy) from 1959 directed by a group of young directors, who graduated Film School in Łódź, Julian Dziedzina, Paweł Komorowski and Walentyna Uszycka, Encounters (Spotkania) by Stanisław Lenartowicz from 1957 and Treasure of Captain Martens (Skarb kapitana Martensa) by Jerzy Passendorfer, 1957.
[11] Well-known Hłasko’s followers are: Monika Kotowska, Marek Nowakowski, Magda Leja, Eugeniusz Kabatc, Stanisław Stanuch. Even today stories are written that have been inspired by Marek Hłasko and are published on the website devoted to the writer, v.: http://www.marekhlasko.republika.pl/index2.htm, 30.09.2011.

[12] Lidia Zonn - film editor of documentaries of the greatest Polish directors such as Krzysztof Kieślowski and Kazimierz Karabasz. 
the characters' dialogues and, at the end of the film, he warns his audience in a patronising tone about the terrible consequences of exposing young people too early to adult disappointments and the dangerous boredom of suburban workers idling on a Saturday afternoon.[13] This adaptation shows the contrast between the innocent beauty of youthful love, and the ugliness and fatigue that commonly provide its surroundings. There is no dramatic portrayal of events. Instead, the narrator solemnly paints a sociological picture illustrating contemporary problems including boredom, alcohol addiction, violence and the stifling of life in the oppressive and overwhelming communist time.

The subsequent film adaptation, The First Step in the Clouds (Pierwszy krok w chmurach) realised by Ewa Pytka in 1993, is markedly different. This story concentrates on the feelings of the two young people (including affection-filled scenes of the couple eating cherries together and delicately caressing each other somewhere in a meadow far from the city centre) with their intimacy then destroyed by the three men. The film focuses on the beautiful moments shared by the young couple and then its savage destruction. There is no explicit moral statement and no sympathy shown, or reason offered, for the barbaric actions of the intruders.

The third film based on this story is First blood (Pierwsza krew) in 2009 and is directed by Grzegorz Krawiec. The film is based in modern day Poland but the film's protagonists, although younger, share the same predicament as their communist incarnations: they are poor, illeducated and have no hope for progress or opportunity for escape. This is a new capitalist country where those with money can afford to live well in the new world, while those without remain as they did before 1989. This film portrays the in-love couple as a part of the privileged class from the city, searching the forgotten suburbs for an isolated place to make love. The assault on the couple is seen to be motivated by jealousy inspired primarily by the financial gap between the couple and their attackers. Whilst they are shown to be partly contrite, the feelings of tiredness, hopelessness and boredom are seen to overwhelm any sense the aggressors had that what they did was wrong.

In these three adaptations of the same piece of prose we can see different focuses among the directors. Two of the films draw attention to the social gap but at different times, one in the communist era and the other in the time of capitalism. Pytka's film eschews social commentary, focussing instead on the fragility of innocence.

Beautiful Girl (Śliczna dziewczyna) has been adapted by Stanisław Lenartowicz as Encounters (Spotkania) in 1957 and by Jori Pölkki as Beautiful Children (Piękne dzieci) in 1993. Lenartowicz's feature film shortened and changed the original story, showing only the

[13] In this film we can see one of the oldest Warsaw district - Powiśle. 
young characters conversing in vulgar language about how to obtain money to discard an unwanted pregnancy. Pölkki takes a different approach, showing not only the boy and girl but, remaining true to Hłasko's own story, also the passers-by who comment on the girl's appearance, her beauty evoking within them sorrow and memories of lost love and unfulfilled dreams.[14] The film contains many strong contrasts, the most significant of which being the external beauty of the girl with her lack of inner beauty as demonstrated through her profane and spiteful language.

The use of a woman's words and their impact on the listener provides the theme for Hłasko's The Most Sacred Words of Our Life (Najświętsze słowa naszego życia) and its adaptation The Morning (Poranek), realised in 1957 in black and white by Andrzej Herman. Upon meeting his work colleagues the morning after losing his virginity the night before, the main character is greatly perturbed when he discovers that the hitherto seemingly precious words spoken to him by his lover, the sweetly endearing yet promiscuous Basia, "You smell like milk, like a puppy", was little more than a stock phrase she recycled among her many lovers. The themes of first love, betrayal and disappointment are always present in Marek Hłasko's prose and are depicted in this film.

Similar themes are encountered in the film Pawnshop of Illusions (Lombard złudzeń), directed by Renata Mazur in 1985 and based on Hłasko's The Most Holy Words In Our Life. A public house provides the setting wherein conversations between two lovers, and then a divorced wife and her rival mistress, deal with treachery, drunkenness, shattered illusions and love. Strong acting performances and Hłasko's dialogue intensify the drama from the scenes as emotions collide and painful truths obliterate fantastical notions of love. The director omits the second part of the original story, whereupon a jilted girl requests from a young boy that he become a writer in the future to emulate her former lover. In my opinion this is a discerning move as it is an artificial and poorly contrived ending that is ill-suited to the well constructed and intelligent literary tale that precedes it, and the film is all the more powerful without it.

Drunkenness, shattered illusion and love are present in Hłasko's epic story The Noose[15] (Pętla) about a young yet experienced man despairing of his empty life, lost ideals and desires. He is now a loser, as he refers to himself, who tries to escape through alcohol and finally suicide. This literary work was a source of inspiration for Grzegorz Kempinsky in 1986 who created and filmed a theatre per-

[14] Played by Renata Dancewicz - Polish actress starred in popular films in the 90's such as Colonel Kwiatkowski (Pułkownik Kwiatkowski) directed by Kazimierz Kutz or Extradition (Ekstradycja) made by Wojciech Wójcik.
[15] There is also a great feature film based on Hłasko's story made by Wojciech Jerzy Has in 1957 which adapted the time, space, characters and reality, and in doing so created a very individual but beautiful and valuable film belonging with the classics of Polish cinema. 
formance, limited to the first part of the Hłasko's story by the same title. The film consists of only the actor on the stage, and as such lacks the heavy presence and symbolism of the Warsovian background that are present in many of the other works. The main character in the film, Kuba, is a lost young man who drinks to excess. We receive no further information about the causes of Kuba's alcoholism and the film is a simple and effective presentation of the character alone on stage. This adaptation shows a director stripping Hłasko's work down, using restricted space, skilled use of strong lighting and the actor's performance and, without a storytelling narrative, to render a compelling account of the loneliness of this sensitive young man and his alcohol addiction, a common problem during communism.

Passions (Namiętności) directed by Wojciech Żogała[16] in 1992 and based on Marek Hłasko’s short story of the same title, deals with the subject of suicide. Given the ambiguities in Hłasko's original story of a doctor and nurse entangled in a strange relationship with each other jointly caring one night for the victim of a failed suicide bid. This is a difficult choice of story to base a film without developing on the author's original opaque work. Nonetheless, the film portrays the themes shared with the others, including disillusionment, loneliness, the sense of a failed life (the mature doctor) and blind faith in love (the young nurse).

The same story was adapted differently in The Duty (Dyzur) by Klaudiusz Kasprzak in 1995. Kasprzak expanded on the original story to articulate its themes more fully, so we have additional scenes and edited dialogue, and the removal of the main character's monologue, to adapt it to the nature of the characters. Kasprzak's approach resulted in a well-made short film about a defeated and disappointed doctor who finally finds solace in the arms of a young nurse.

A very powerful student adaptation of a Marek Hłasko story is the film The Cross (Krzyż), directed by Andrzej Dec in 1988. This time faithful to its original source, it is shot in black and white, serving as a stark portrayal of the final meeting between a prisoner sentenced to death and his parents, and perfectly captures the atmosphere of the writer's prose. Unchanged dialogues full of misunderstandings, brief presentation of the characters, an unexpected punch line - all these hallmarks of Hłasko's fiction can be found in this short film. From the conversation between archetypal members of the traditional Polish family we can discover the drama of previous events where, for the father, the farm and the good opinion of others is more important than the happiness of his son who wants to marry one poor and pregnant girl. Instead he has to kill her. Today this extremely sad and touching story remains relevant concerning the difficult relationship between

[16] Wojciech Żogała - production designer and interior decorator of many polish films such as: $E d i$ (Edi) and Mistrz (The Master) directed by Piotr Trza- skalski and Kolysanka (The Lullaby) made by Juliusz Machulski. 
a father and a son and how the obedience of the latter to the former can result in tragic consequences.

Hłasko's thriller-detective story The Fugitive (Zbieg), about a hardened criminal who escapes prison only to long for return after discovering people outside prison are more cynical and deadly than those inside, provides the basis for two films. The Second Day of Freedom (Drugi dzień wolności) made in 1988 by Jerzy Krysiak is a faithful reproduction of the plot of the original story. Krysiak, however, takes an innovative and experimental approach to the photography and music, starting the film with a series of strange images that are seemingly disconnected accompanied with a peculiar jazz soundtrack. On reflection, the audience can soon tie this disorientating presentation with the quintessence of the story, being the falsified sense of freedom prevailing at the time (Polish October - Gomulka's thaw) [17], as well as the absurd situation of the fugitive, having experienced greater freedom in prison than on the streets.

The same is with The Civilian (Cywil) from the 1981 - an adaptation by Janusz Petelski.[18] This film is less concerned with conveying the sense of the time with more emphasis on the plot. There are no famous suburbs or outlaws from the underclass. There is only a wearied detective shortly before retirement whose ambition is to catch a hardened criminal. However the film still shows us the same important issues for the author of The First Step In the Clouds such as loneliness of individual in the cruel and complicated world.

The last of the short films is a screen adaptation of Marek Hłasko's Cemeteries (Cmentarze) entitled: ...Until such a moment comes... (...Aiz przychodzi taka chwila...) adapted by Waldemar Strajch in 1990. The director realises the first part of the text that tells the story of an arrested drunk man trying to find out why he has been arrested. The action takes place only in a prison cell. Nevertheless, it captures the absurdity of the situation and the hopeless position of Hłasko's character. Kowalski (as Kuba with The Noose or Joseph K. from Franz Kafka's The Trial) wants to discover the truth and wants to prove his innocence. However, it appears that in communist Poland, described by Hłasko or Strajch, the truth does not exist, and he fails. This is a faithful adaptation of the original story and demonstrates how Hłasko's work could be ripe for directors to transfer directly to the screen.

All these students' works are either graduate films, examination or practice pieces and provide interesting and varied interpretations of Marek Hłasko’s prose. His literature has proved to be useful material for students' work for many reasons. His stories are short so young

[17] Polish October, also known as October 1956, Polish thaw, or Gomułka's thaw, marked a change in the Polish internal political scene in the second half of 1956.
[18] The son of Czesław Petelski who adapted in 1958 another Hłasko's story The Depot of the Death (Baza ludzi umarlych). 
directors and directors of photography do not need to cut or edit them, choose between various elements or add new scenes. They provide almost ready-made scenarios comprising mainly of dialogues and action without excessive monologue or description of the setting (which can be helpful for directors but difficult to relay faithfully to the screen). At the same time, their basic original state also enables the directors to develop and advance stories to fit their own purposes. Hłasko presented Polish reality during the difficult time of communism and portrayed universal themes that have remained relevant post 1989, and this is an area that appeals to young directors who want to portray the struggles of modern life compared with the past. He wrote from the perspective of a man in his twenties, full of ideas, a young rebel who wanted, through his stories, to change the world. These are characteristics shared by many of the students of the Film School in Łódź from 1957 to the present day. Whilst not all may have wanted to change the world through their work, they have certainly wanted to leave a mark on Polish cinematography.

Marek Hłasko’s works are bountiful for young student directors in terms of themes with ongoing social and personal relevance, and their often stark composition gave the directors both structure to work to and flexibility with which to adapt to their own purposes. First the young directors felt a connection with Hłasko's works and its themes, and second they felt able to relate their experiences through the medium and setting of their choice. They commonly retained the meanings, main ideas and themes of the original works, and often changed the circumstances, background or time. Hłasko's stories were fit for students seeking the opportunity to display creative interpretative techniques as well as for those looking to practice and enhance their filmmaking skills. That the students so frequently chose to convey in their works the existential issues identified and portrayed by Hłasko is testament to his works and themes having remained relevant to the current day. 